\title{
Flora of Singapore precursors, 21: New records of Euphorbiaceae for Singapore
}

\author{
P.C. van Welzen ${ }^{1}$, D.J. Middleton ${ }^{2} \&$ S. Lindsay ${ }^{3}$ \\ ${ }^{1}$ Naturalis Biodiversity Center, P.O. Box 9517, 2300 RA Leiden, \\ The Netherlands; Institute of Biology Leiden, P.O. Box 9504, \\ 2300 RA Leiden, The Netherlands \\ peter.vanwelzen@naturalis.nl \\ ${ }^{2}$ Singapore Botanic Gardens, National Parks Board, \\ 1 Cluny Road, 259569 Singapore \\ ${ }^{3}$ Native Plant Centre, Horticulture and Community Gardening Division, \\ National Parks Board, 100K Pasir Panjang Road, \\ 118526 Singapore
}

ABSTRACT. Seven species of Euphorbiaceae are newly recorded for Singapore of which five are presumed native, one is cryptogenic and one is naturalised. One name is lectotypified. The conservation status of the native species is discussed.

Keywords. Acalypha, Blumeodendron, Endospermum, Mallotus

\section{Introduction}

In preparation for an account of the Euphorbiaceae for the Flora of Singapore a number of species were identified from material collected in Singapore that were previously not recorded for the country (Schaeffer, 1971; Keng, 1990; Turner, 1993; Sierra \& van Welzen, 2005; Chong et al., 2009; Arias Guerrero \& van Welzen, 2011; Stoops \& van Welzen, 2013; Ottens-Treurniet \& van Welzen, 2016). Five of these species are otherwise widespread in the region in habitats also present in Singapore and are, therefore, presumed to be native in Singapore. One species is treated as cryptogenic. The seventh species, Acalypha arvensis Poepp., is a neotropical weedy species that was first collected in Singapore in 1955. These species had been overlooked in Singapore as the material had not previously been critically studied and had either been misidentified or not identified except to genus. Global and Singapore national conservation assessments are given for the native species following the guidelines in IUCN (2017) and Davison et al. (2008). Herbarium codes follow Thiers (continuously updated).

\section{New records of native and cryptogenic species}

1. Blumeodendron kurzii (Hook.f.) J.J.Sm., Meded. Dept. Landb. Ned.-Indië 10: 463 (1910). - Mallotus kurzii Hook.f., Fl. Brit. India 5, fasc. 14: 427 (1887). - 
TYPE: [Malaysia], Perak, Larut, January 1885, King's collector 7114 (lectotype K [K001057450], designated by Ottens \& van Welzen, Blumea 61: 72 (2016)). (Fig. 1).

Blumeodendron tokbrai auct. non (Blume) Kurz: Keng, Concise Fl. Singapore, vol. 1, Gymn. Dicot.: 107 (1990), p.p.; Turner, Gard. Bull. Singapore 45: 81 (1993), p.p.; Turner \& Tan in Wee \& Ng (eds), First Look Biodivers. Singapore: 115 (1994), p.p.; Ng \& Wee (eds), Singapore Red Data Book: 284 (1994), p.p.; Tan et al. in Davison et al. (eds), Singapore Red Data Book, ed. 2: 222 (2008), p.p.; Chong et al., Checkl. Vasc. P1. Fl. Singapore: 19, 130, 219 (2009), p.p.

Tree, dioecious, to $35 \mathrm{~m}$ high, bole to $30 \mathrm{~m}$ high, dbh to $60 \mathrm{~cm}$; sometimes slightly fluted at base, flutes c. $1.5 \mathrm{~m}$ high, extending outwards to $50 \mathrm{~cm}$, sometimes a short buttress; flowering branches $4-22 \mathrm{~mm}$ in diam., round to sometimes triangular in section below the distinctly thickened nodes, internodes to $18 \mathrm{~cm}$ long; terminal bud surrounded by round or triangular axillary buds. Outer bark dark brown to greyish, to rarely black, smooth to cracked in irregular pieces to (powdery) scaly, soft to hard, 0.5-6 mm thick; inner bark dark red outside to brown inside, 3-6 mm thick, sap absent to clear; sapwood white to red to brown; heartwood yellowish red to pinkish brown (to rays brown). Indumentum consisting of small, orange, lepidote hairs. Leaves always in whorls of 3-5 per node, young ones yellow-green to light green; petiole $1.3-12 \mathrm{~cm}$ long, thinnest part 1-4 mm diam., dirty green to brown when fresh, to dark brown when dry, basal pulvinus c. $4 \mathrm{~mm}$ diam., upper pulvinus larger and mainly developed abaxially; blade (ovate to) elliptic to oblong to obovate, $8.8-42(-51) \times$ 4.4-23.7(-26.5) cm, 1.3-2.5 times longer than wide, coriaceous, symmetric, glabrous, (dark green to) light brown on both sides when dry, base obtuse to cuneate, margin usually light brown or yellow when dry, flat to revolute, apex acuminate (to cuspidate), extrafloral nectaries positioned adaxially, often 2 near base, also $0-19$ on both sides along midrib, and 6-36 along margin; marginal vein distinct, secondary veins 5-12 pairs, clearly visible, for c. $2 / 3$ of their length parallel to each other, tertiary veins perpendicular to midrib, hardly visible above, raised beneath, $0.3-0.4 \mathrm{~cm}$ apart, higher order veins reticulate, indistinct. Inflorescences cauliflorous, ramiflorous, axillary and terminal, shortly thyrsoid, almost fasciculate; staminate inflorescences to $1.7 \mathrm{~cm}$ long, more than 8 branches together, pistillate infloresences to $3 \mathrm{~cm}$ long, c. 4 branches together; bracts absent. Flowers yellowish, yellow-green or light green; pedicel 4-10 $\mathrm{mm}$ long; staminate buds globose, c. 35 per inflorescence, c. $3.9 \mathrm{~mm}$ diam.; petals lacking; staminate flowers 7-7.5 mm diam.; pedicel c. $10 \mathrm{~mm}$ long; sepals 3, 4-5 $\times 2.2-3.5 \mathrm{~mm}$; disk lobes yellow; stamens $20-25$, filaments $2-10 \mathrm{~mm}$ long, yellow, anthers $0.75-1 \mathrm{~mm}$ long, yellow to later fulvous. Pistillate flowers not seen. Fruits capsular, subglobose, 3.3-5.8 $\times 2.8-4.6 \mathrm{~cm}, 2-$ or 3-locular, dark brown when dry; pedicel thickened, c. $1 \mathrm{~cm}$ long, c. $6 \mathrm{~mm}$ diam., abscission zone positioned in the middle to subapically; sepals usually persistent; disc distinct, dark brown when dry; wall 2-4 mm thick, surface knobbly; margin not or slightly thickened as very low ridges; endocarp enclosing two or three seeds (1 per locule); remnant style very sturdy, at most $1 \mathrm{~mm}$ long; stigmas usually persistent, to $5 \mathrm{~mm}$ long, spreading. 


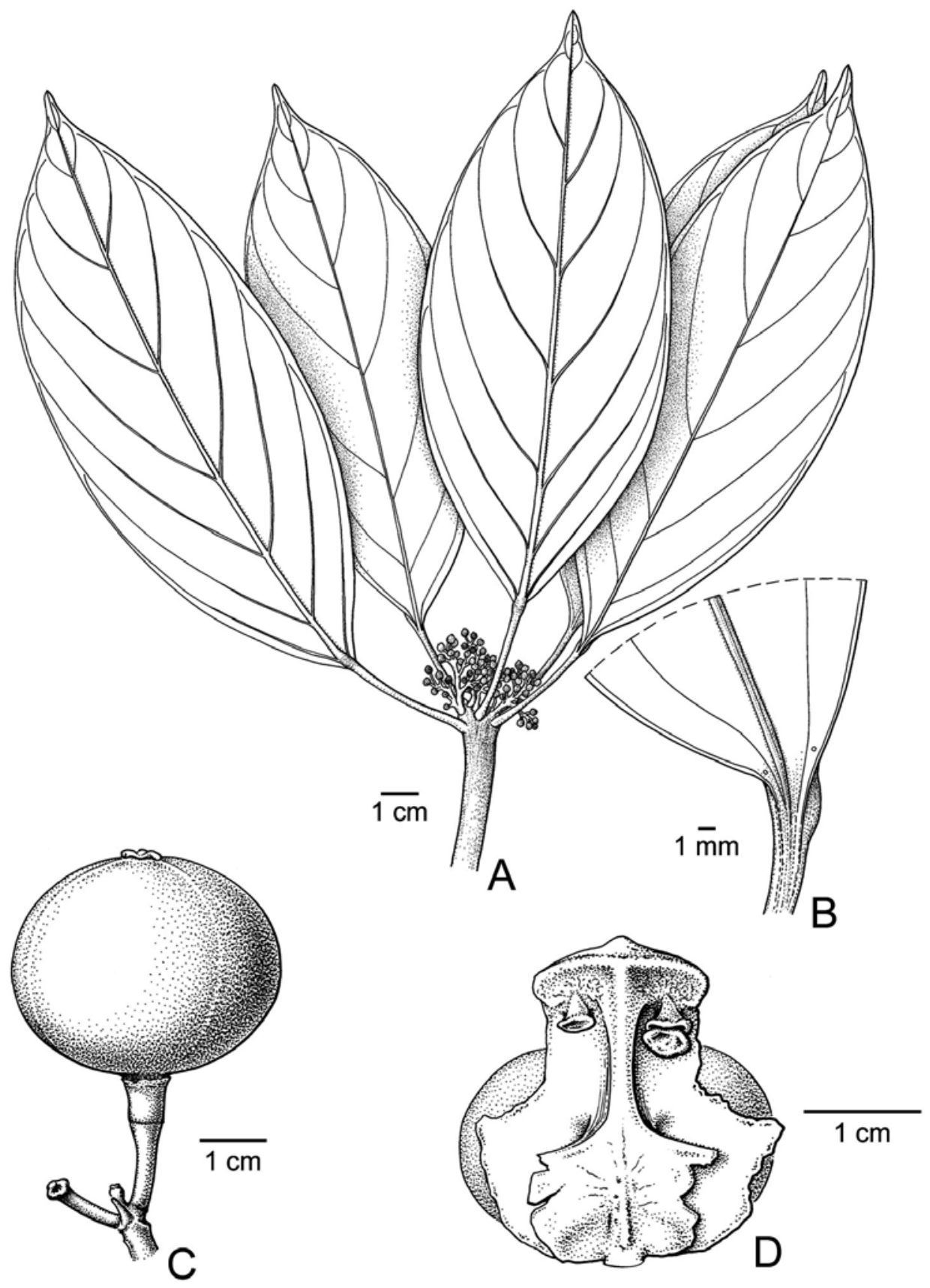

Fig. 1. Blumeodendron kurzii (Hook.f.) J.J.Sm. A. Habit with whorled leaves and short inflorescences. B. Base of leaf blade with two small extrafloral nectaries [Forbes 2874, L]. C. Fruit. D. Opened fruit with columella with apically remnants of seed attachment, and basally with parts of septa still attached, in background a single seed. C from SAN (Wood \& Kilang) 16618; D from SAN (Mikil) 31599; all L). Drawing: A \& B by Anita Walsmit Sachs; C \& D by Esmée Winkel. 
Seeds bean-shaped, but one end smaller than the other, $2.1-2.2 \times 1.3-1.6 \times$ c. $1.2 \mathrm{~cm}$, dry, dark brown, attached in middle; sarcotesta yellow.

Distribution. Peninsular Thailand, Peninsular Malaysia, Singapore, Sumatra, Borneo, Java and the Philippines (Luzon, Samar).

Ecology. In Singapore known only from freshwater swamp forest but across its range known from a wide variety of forest types.

Provisional IUCN conservation assessment. Globally Least Concern (LC) as this species is widespread and found in a variety of habitats. Assessed here as Critically Endangered (CR/D) in Singapore as it is currently only known from one tree in Nee Soon freshwater swamp forest.

Specimens examined. SINGAPORE: Jurong: 19 Oct 1932, Corners.n. (SING [SING0012643]); Bukit Mandai: 22 Jul 1940, Kiah 37113 (SING [SING0012663]); 12 Aug 1940, Kiah s.n. (SING [SING0012668]); Nee Soon: 22 Jun 2011, Lua \& Sha SING2011-242 (SING [SING0164200]).

Notes. The older material had all previously been misidentified as Blumeodendron tokbrai (Blume) Kurz which is also found in Singapore but can be distinguished from Blumeodendron kurzii in having leaves alternate to pseudo-opposite or pseudowhorled (in whorls of 3-5 per node in B. kurzii) and inflorescences not fasciculate and to $20 \mathrm{~cm}$ long (almost fasciculate and $<3 \mathrm{~cm}$ long in B. kurzii).

2. Blumeodendron subrotundifolium (Elmer) Merr., Philipp. J. Sci., C 7: 384 (1913 [1912]). - Sapium subrotundifolium Elmer, Leafl. Philipp. Bot. 3: 930 (1910), as 'subrotundifolia'. - TYPE: Philippines, Sibuyan, Capiz Prov., Magallanes (Mt Giting-Giting), April 1910, Elmer 12349 (lectotype L [L.2192761], designated here; isolectotypes A [A00048758], BISH [BISH1001680], G [G00434214], GH [GH00061233], HBG [HBG516539], K [K001057457], NY [NY00273237], US [US00096695]). (Fig. 2).

Blumeodendron tokbrai auct. non (Blume) Kurz: Keng, Concise Fl. Singapore, vol. 1, Gymn. Dicot.: 107 (1990), p.p.; Turner, Gard. Bull. Singapore 45: 81 (1993), p.p.; Turner \& Tan in Wee \& Ng (eds), First Look Biodivers. Singapore: 115 (1994), p.p.; Ng \& Wee (eds), Singapore Red Data Book: 284 (1994), p.p.; Tan et al. in Davison et al. (eds), Singapore Red Data Book, ed. 2: 222 (2008), p.p.; Chong et al., Checkl. Vasc. Pl. Fl. Singapore: 19, 130, 219 (2009), p.p.; Turner \& Chua, Checkl. Vasc. Pl. Sp. Bukit Timah Nat. Res.: 28 (2011), p.p.; Ho et al., Gard. Bull. Singapore 71(Suppl. 1): 83 (2019).

Tree, dioecious, to $50 \mathrm{~m}$ high, bole to $25 \mathrm{~m}$ high, dbh to $91 \mathrm{~cm}$; bole sometimes fluted or with low buttresses to $1.5 \mathrm{~m}$ high, extending out to c. $1.5 \mathrm{~m}, \mathrm{c} .2 .5 \mathrm{~cm}$ thick; flowering 


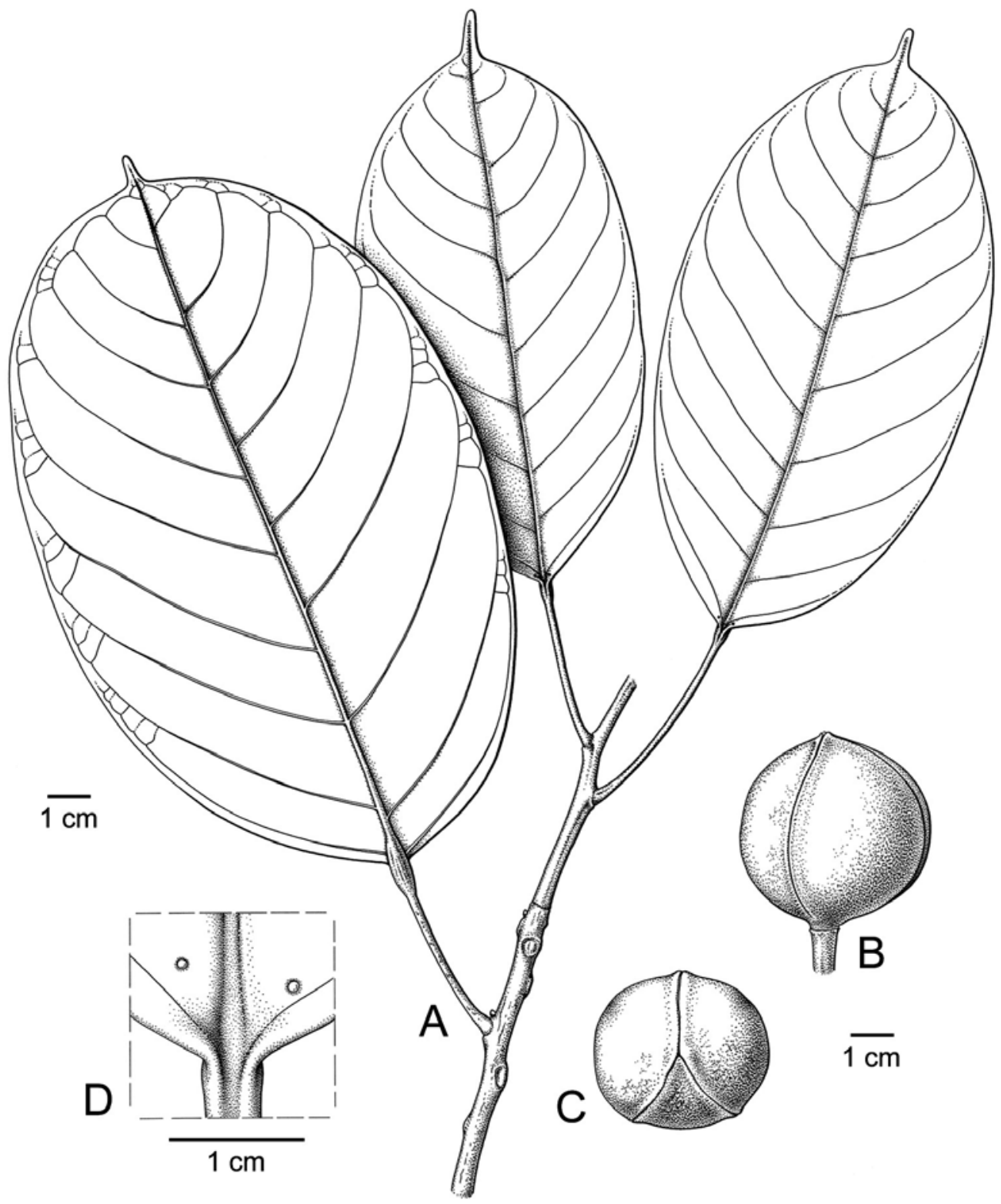

Fig. 2. Blumeodendron subrotundifolium (Elmer) Merr. A. Habit. B. Fruit in lateral view. C. Fruit in top view. D. Base of upper leaf surface with extrafloral nectaries. A \& B from Kessler et al. Berau 763; C \& D from Nooteboom \& Chai 2317; all L. Drawn by Esmée Winkel.

branches 3 (staminate)-28 (pistillate) mm diam., generally round, with orange early glabrescent lepidote hairs, internodes to c. $5 \mathrm{~cm}$ long, nodes slightly thickened. Outer bark brown to yellow-brown to grey, fissured to scaly to flaky, soft, lenticellate, 1-3 $\mathrm{mm}$ thick; inner bark red to dark brown, sometimes laminated, hard, 8-10 mm thick; sometimes red watery exudate reported; sapwood cream to reddish brown, very hard; 
heartwood brown. Leaves alternate to subopposite or in pseudo-whorls of 3; petiole 2.4-18.5 cm long, round, thinnest part 1-15 mm diam., basal pulvinus 2-20 mm diam., lepidote hairs orange; blade elliptic, $6.2-46 \times 3-22 \mathrm{~cm}, 1.2-3.1$ times longer than wide, coriaceous to very coriaceous, symmetric, glabrous, base emarginate to rounded to cuneate, margin recurved, apex acuminate (to cuspidate), both surfaces smooth, extrafloral nectaries on both surfaces along midrib 2-26, along margin 8-20, adaxial surface usually drying shiny brown, abaxial surface drying lighter dull brown; marginal vein indistinct, secondary veins pinnate, 3 or $4(-11)$ pairs, sometimes very parallel, at c. $52^{\circ}$ angle with midrib, tertiary veins raised below, perpendicular to midrib and/or only to secondary veins, higher order veins indistinct. Inflorescences cauliflorous, ramiflorous to axillary, peduncle c. $1.3 \mathrm{~cm}$ long, brown, rachis c. $1 \mathrm{~mm}$ diam.; staminate inflorescences often paired, to $4.5 \mathrm{~cm}$ long; pistillate inflorescences single, to $2.3 \mathrm{~cm}$ long, rachis thickening during fruit set to c. $4 \mathrm{~mm}$; bracts/bracteoles (below flowers) triangular, c. $5 \times 2 \mathrm{~mm}$, margin undulate, lepidote hairs orange. Flowers pale yellow to (greenish) red, regular; calyx lobes basally or completely connate; petals absent; disc annular, indistinct. Staminate flowers 5-6 mm diam.; pedicel 3-25 mm long, brown; buds 1.5-5 mm diam.; sepals 2 or 3, ovate, 4-5.5 $\times$ 3-5 mm; disc lobes yellow; stamens 25-40, yellow, filaments $1.5-3 \mathrm{~mm}$ long, anthers 0.4-0.5 mm long. Pistillate flowers seen only in fruit development stages; sepals 4 or 5 , c. $1.5 \times 2.2 \mathrm{~mm}$; ovary 2 - or 3-locular, dull dirty purple; style c. $1 \mathrm{~mm}$ long, sturdy, stigmas c. $2.5 \mathrm{~mm}$ long, recurved, greenish. Fruits capsular, subglobular (smaller) to ovoid (larger), 2.9-4.5 × 3.5-6 cm, green (unripe) to yellow to orange-yellow (or red); pedicel c. $1.5 \mathrm{~cm}$ long, to c. $0.8 \mathrm{~cm}$ diam., abscission zone in the middle; wall $2-4 \mathrm{~mm}$ thick, dark brown when dry, margin slightly thickened, but without ridges, surface knobbly; endocarp enclosing two or three seeds; stigma mostly persistent. Seeds beanlike to flattened at one-side, $2.3-3.4 \times 1.6-2.4 \times 1.1-1.3 \mathrm{~cm}$, dry, attached in middle; sarcotesta cream to purple.

Distribution. Peninsular Thailand, Peninsular Malaysia, Singapore, Sumatra, Borneo and the Philippines.

Ecology. In Singapore known from both primary and secondary evergreen forest in the Central Catchment and Bukit Timah.

Provisional IUCN conservation assessment. Globally Least Concern (LC). Assessed here as Vulnerable (VU/D) in Singapore based on an estimate of fewer than 1000 trees in the country.

Specimens examined. SINGAPORE: Bukit Timah: 3 Aug 1938, Ngadiman SFN 35596 (SING [SING0012639, SING0231891]); 13 Feb 1946, Henderson SFN 37296(SING [SING0012641]); 24 Jun 1953, Sinclair SFN 39686 (SING [SING0012640]); 23 Oct 1969, Mhd Noor MN 690 (SING [SING0012655]); 16 Jan 1970, Mhd Noor MN 873 (SING [SING0012657]); 4 Aug 1970, Mhd Noor MN 1304 (SING [SING0012653]); 8 Dec 1970, Mhd Noor MN 1445 (SING [SING0012652]); 22 Dec 1970, Mhd Noor MN 1511 (SING [SING0012650]); 5 Mar 1973, 
Mhd Noor 1587 (SING [SING0012661]); 17 Dec 1973, Hamzah s.n. (SING [SING0012645]); 4 Feb 2004, Samsuri et al. EP 17 (SING [SING0051172]); 5 Jan 2010, Gwee SING2010-086 (SING [SING0144077]); 13 Dec 2018, Lim et al. CTFS C3-22458 (SING [SING0289018]); Upper Peirce: 17 Nov 2009, Gwee SING2009-471 (SING [SING0138027]); Seletar: Seletar Forest, 17 Nov 1994, Nura Abdul Karim et al. NK 179 (SING [SING0035240]).

Notes. The material that had been previously determined to species had all been misidentified as Blumeodendron tokbrai but which can be distinguished from Blumeodendron subrotundifolium in its generally thinner leaf blades, longer staminate and pistillate inflorescences, and thicker fruit wall. Blumeodendron subrotundifolium also resembles $B$. kurzii in leaf-shape, colour of dried leaves and leaf texture. However, the leaves do not arise in whorls from thickened nodes. Also, the inflorescences are generally longer than the almost fasciculate ones of B. kurzii.

3. Endospermum peltatum Merr., Publ. Bur. Sci. Gov. Lab. 35: 35 (1906 [1905]). TYPE: Philippines, Luzon, Tayabas Prov., Pagbilao, April-May 1903, Merrill 2604 ['2603' in protologue] (lectotype K [K000254474], designated by Schaeffer, Blumea 19: 188 (1971); isolectotype BM [BM000951533]).

Endospermum diadenum auct. non (Miq.) Airy Shaw: Keng, Concise Fl. Singapore, vol. 1, Gymn. Dicot.: 109 (1990), p.p.; Turner, Gard. Bull. Singapore 45: 83 (1993), p.p.; Turner \& Tan in Wee \& Ng (eds), First Look Biodivers. Singapore: 115 (1994), p.p.; Ng \& Wee (eds), Singapore Red Data Book: 285 (1994), p.p.; Tan et al. in Davison et al. (eds), Singapore Red Data Book, ed. 2: 222 (2008), p.p.; Chong et al., Checkl. Vasc. Pl. Fl. Singapore: 39, 130, 221 (2009), p.p.; Turner \& Chua, Checkl. Vasc. P1. Sp. Bukit Timah Nat. Res.: 29 (2011), p.p.

Endospermum malaccense auct. non Benth. ex Müll.Arg.: Ridley, Fl. Malay Penins. 3: 305 (1924), p.p.

Tree, dioecious, to $50 \mathrm{~m}$ high, bole to $29 \mathrm{~m}$ high, dbh $16-90 \mathrm{~cm}$, without or with buttresses to $3 \mathrm{~m}$ high, extending out to c. $2 \mathrm{~m}$; branches with a hard pith, flowering ones $8-11 \mathrm{~mm}$ thick, pilose. Outer bark white to brown to grey, $0.5-13 \mathrm{~mm}$ thick, smooth; inner bark pale yellow to orange to brown; sapwood white to straw-coloured; heartwood straw-coloured, soft. Indumentum consisting of stellately bundled and simple hairs. Stipules $4.8-5.8 \times 1.7-2.5 \mathrm{~mm}$, densely hairy on both sides. Leaves: petiole $7.5-26 \mathrm{~cm}$ long, channelled above at the base, densely pilose; blade narrowly to broadly ovate, $11-29.8 \times 8.7-23.5 \mathrm{~cm}, 1.2-1.3$ times longer than wide, coriaceous, base peltate or not, cordate to rounded (to acute), abaxially with 2 large cylindrical extrafloral nectaries near the insertion, 1.3-1.9 $\times 1.1-1.8 \mathrm{~mm}$, rimless, margin entire with numerous minute glands, apex acute to acuminate, upper surface glabrous or sparsely covered with strigose simple hairs and/or stellately bundled hairs, lower surface densely pilose with stellately bundled hairs, with at most 5 equal hairs in a 
bundle, and/or simple hairs, lamina visible under indumentum, greyish green to pale green, dull and with glands in the more marginal bifurcations of the veins, domatia absent; venation yellow beneath, basally tripliveined or palmate with 5-9 basal veins, upper part pinnate with 5-8 pairs of veins. Inflorescences thyrsoid panicles, densely hairy, to $42 \mathrm{~cm}$ long with the first branches to $13 \mathrm{~cm}$ long; bracts triangular, $1.8-3.2$ $\times 1.8-1.9 \mathrm{~mm}$, apex acuminate, pilose both sides, often with 2 flat round glands near the base, c. $0.5 \mathrm{~mm}$ wide. Flowers regular; calyx lobes basally or completely connate; petals absent; disc annular, indistinct. Staminate flowers white to yellow to pale green, sessile or with a pedicel to $1.5 \mathrm{~mm}$ long, pilose; calyx 4-lobed, lobes $1.5-1.7 \times 1.7-2.1$ $\mathrm{mm}$, basally connate, densely hairy outside, pilose inside; stamens 9 or 10, androphore obovate, $1.8-2.2 \times 0.9-1.1 \mathrm{~mm}$, free part of filaments $0.8-1.5 \mathrm{~mm}$ long, anthers 3 -thecate, $0.4-0.5 \times 0.8-1 \mathrm{~mm}$; pistillode cylindrical, splitting into 2 or 3 parts, 0.5 $0.6 \times 0.4-0.8 \mathrm{~mm}$, sparsely hairy on the top. Pistillate flowers single per node, green to yellow, sessile or with a pedicel to $3.2 \mathrm{~mm}$ long; calyx 4-lobed or toothed, lobes indistinct, 1-1.4 × 2-2.6 mm, basally connate, densely hairy outside, pilose inside; ovary globose, 2- or 3(-4)-locular, 1.5-2.8 × 1-2 mm; stigma flattened, 1.5-1.9 $\times$ 0.3-0.6 mm, glabrous. Fruits indehiscent, brown to green to yellow, globose, 5-8.2 $\times$ 6-2.7 mm, with or without 3 triangular lobes on top, lobes $0.4-1 \mathrm{~mm}$ long, often with a groove on the inside. Seeds globose, $3.4-5 \times 3.2-3.8 \mathrm{~mm}$, dry, ecarunculate.

Distribution. Andaman Islands, Peninsular Thailand, Peninsular Malaysia, Singapore, Borneo and the Philippines.

Ecology. In Singapore known from both primary and secondary evergreen forest in the Central Catchment and Bukit Timah, and from Nee Soon freshwater swamp forest.

Provisional IUCN conservation assessment. Globally Least Concern (LC) as this species is widespread and not uncommon. Assessed here as Vulnerable (VU/D) in Singapore based on an estimate of fewer than 1000 trees in the country.

Specimens examined. SINGAPORE: Bukit Timah: Catchment Contour Path, 9 Oct 1969, Mhd Noor MN 646 (SING [SING0199812]); Rock Path, 19 Nov 1969, Mhd Noor MN 749 (SING [SING0199312]); North View Path, 14 Jul 1970, Mhd Noor MN 1097 (SING [SING0199313]); Jungle Fall Path, 8 Jan 1970, Mhd Noor MN 849 (SING [SING0199813]), Mhd Noor MN 850 (SING [SING0200051]), Mhd Noor MN 854 (SING [SING0200052]), 8 Sep 1970, Mhd Noor MN 1346 (SING [SING0200053]); Hampstead Path, 8 Dec 1970, Mhd Noor MN 1443 (SING [SING0200054]); 6 Dec 2018, Lim et al. CTFS C2-22279 (SING [SING0289000]); Changi: Hendon Road, 23 Apr 2004, Ganesan \& Yap SKG 71 (SING [SING0055019]); Chestnut: Chestnut Track, 26 Aug 2008, Gwee SING2008-313 (SING [SING0114856]); Upper Peirce: 19 Jan 2010, Gwee SING2010-142 (SING [SING0144680]); Nee Soon: 29 Jul 2003, Samsuri et al. NES 156 (SING [SING0045860]); Rifle Range, 2 Oct 2017, Lua et al. SING2017-474 (SING [SING0267842]).

Notes. The material that had been previously determined to species had mostly been misidentified as Endospermum malaccense Benth. ex Müll.Arg., which is now treated 
as a synonym of Endospermum diadenum (Miq.) Airy Shaw. Endospermum peltatum differs from Endospermum diadenum in having abaxial extrafloral nectaries cylindrical and 1.3-1.9 × 1.1-1.8 mm (knob-like and 0.4-0.5 × 1.5-2.2 $\mathrm{mm}$ in E. diadenum), inflorescences in panicles (racemes in E. diadenum), and in several other vegetative and floral characters.

The epithet 'peltatum' indicates that the leaf base is peltate. However, this character is variable and non-peltate leaves, even together with peltate ones, are found.

4. Endospermum quadriloculare Pax \& K.Hoffm. in Engler, Pflanzenr. IV, fam. 147 IV (Heft 52): 36, fig. 10 (1912). - TYPE: [Indonesia], Sumatra, Palembang, 1880, Forbes 2751 (lectotype BM [BM000951535], designated by Schaeffer, Blumea 19: 190 (1971); isolectotypes GH [GH00106142], K [K000254477], L [L0016205, L0016206, L0016207, L0016208], P [P00717057]). (Fig. 3).

Tree, dioecious, but some pistillate flowers seemingly bisexual, to $40 \mathrm{~m}$ high, dbh c. $60 \mathrm{~cm}$; without or with buttresses to $2.45 \mathrm{~m}$ high; branches with a hard pith, flowering ones 5.2-7 mm thick, glabrous to sparsely hairy. Outer bark whitish, smooth, with circular rings from scars of leaves and stipules; inner bark yellow; wood white to yellow. Indumentum consisting of minute, stellately bundled hairs. Stipules $4.2-4.7 \times$ 1.4-1.5 mm, pilose. Leaves: petiole 4.9-15.3 cm long, channelled above at the base, glabrous to sparsely hairy; blade elliptic to ovate, $9.2-25 \times 6.3-14.1 \mathrm{~cm}, 1.5-1.8$ times longer than wide, papyraceous to rarely coriaceous, base peltate or not, emarginate to acute, abaxially with or without 1 or 2 lateral cylindrical, extrafloral nectaries near the insertion, 1.1-3 × 1-1.4 mm, rimless, margin somewhat undulate, rarely with minute abaxial glands, apex acute to cuspidate, upper surface glabrous, dark green, glossy, lower surface glabrous to densely covered with minute stellately bundled hairs, duller and paler than above, without domatia; venation basally tripliveined or palmate with 5-7 basal veins of which the 2 outer ones less distinct, upper part pinnate with 4-6 pairs of veins. Inflorescences thyrsoid panicles, densely hairy, to $18 \mathrm{~cm}$ long with the first branches to $6 \mathrm{~cm}$ long; bracts triangular, 1.8-2.4 $\times 1.5-1.6 \mathrm{~mm}$, apex acuminate, densely hairy both sides, often with 2 round glands near the base, c. $1 \mathrm{~mm}$ wide. Flowers regular; calyx lobes basally or completely connate; petals absent; disc annular, indistinct. Staminate flowers pale yellow, with a pedicel to $1.2 \mathrm{~mm}$ long; calyx indistinctly lobed, lobes $1.1-1.2 \times$ c. $1.8 \mathrm{~mm}$, pilose outside, sparsely hairy inside; stamens c. 12, yellow to brown, androphore obovate, $2-2.1 \times 1.2-1.3 \mathrm{~mm}$, free part of filaments c. $0.5 \mathrm{~mm}$ long, anthers 3 -thecate, thecae $0.6-0.8 \times 0.8-0.9 \mathrm{~mm}$; pistillode 3- or 4-lobed, $0.4-0.5 \times$ c. $0.6 \mathrm{~mm}$, sparsely hairy beneath. Pistillate or seemingly bisexual flowers single per node, with a pedicel to $4 \mathrm{~mm}$ long, pilose; calyx indistinctly lobed, lobes 1.3-2.4 × 1.8-3.8 mm, pilose outside and inside; bisexual flowers with or without a cylindrical androgynophore of c. $2.2 \times 0.8 \mathrm{~mm}$, with 8-10 stamens, likely staminodial, at base of ovary, comparable to those of staminate flowers, persistent in fruit; ovary globose (unisexual) to cylindrical (bisexual), (3)4- or 5-locular, 1.3-3 × 0.8-2.4 mm; stigma lobed or not, $2-2.2 \times 0.9-1.4 \mathrm{~mm}$, glabrous, with or without 3 


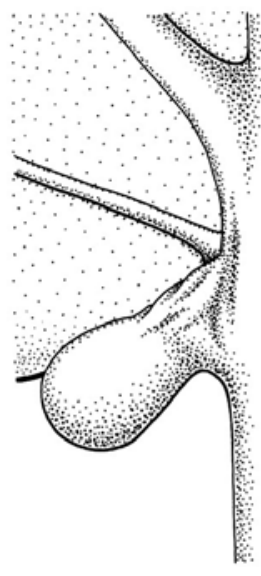

$1 \mathrm{~mm}$

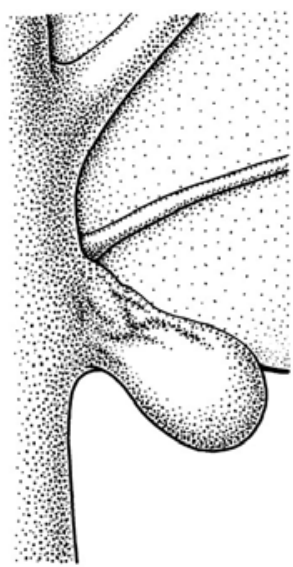

A

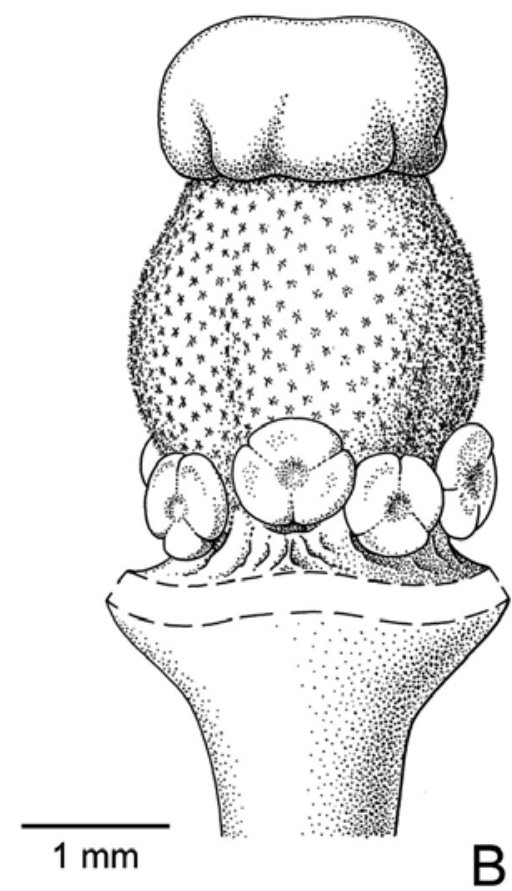

Fig. 3. Endospermum quadriloculare Pax \& K.Hoffm. A. Extrafloral nectaries. B. Exceptional 'hermaphrodite' pistillate flower. A from KEP FRI (Whitmore) 849, L; B from Bangham \& Bangham 739, K. Drawn by Esmée Winkel.

raised triangular lobes on top, c. $1 \mathrm{~mm}$ long, to $2 \mathrm{~mm}$ in fruit, lobes with a groove on the inside. Fruits indehiscent, pale blue to green to brown, globose or ellipsoid, 7.8-13 $\times 6-11 \mathrm{~mm}$, pilose; stigma wider, $1.8-2.1 \times 2.5-3.2 \mathrm{~mm}$. Seeds ellipsoid, 5.9-5.6 $\times$ 2.5-3.2 mm, dry, with a slender caruncle, $1-1.5 \mathrm{~mm}$ long.

Distribution. Thailand, Peninsular Malaysia, Singapore and Sumatra.

Ecology. In Singapore known only from the coastal forest of Labrador Nature Reserve.

Provisional IUCN conservation assessment. Globally not assessed. Presumed nationally extinct in Singapore as it has not been collected or observed since 1976.

Specimen examined. SINGAPORE: Labrador Nature Reserve: 22 Dec 1976, Maxwell 76821 (L [L.2216214]).

Notes. This species is known for Singapore only from a single specimen from Labrador Nature Reserve. 
5. Mallotus barbatus Müll.Arg., Linnaea 34: 184 (1865). - TYPE: [Myanmar], Amherst, 16 February 1827, Unknown (Wallich ?) 1483 [7822C] (lectotype G-DC [G00325890 no. 3] designated by Sierra \& van Welzen, Blumea 50: 251 (2005); isolectotype G-DC [G00325890 no. 2]). (Fig. 4).

Shrub to small tree to $12 \mathrm{~m}$ high, dbh to $15 \mathrm{~cm}$, monoecious or sometimes dioecious. Outer bark finely striate, smooth, to $6 \mathrm{~mm}$ thick, greyish with patches of brown, reddish brown in cross-section; sapwood straw-coloured with pinkish brown streaking. Indumentum dense throughout with stellately bundled hairs and along axes hairy soft enations to $6 \mathrm{~mm}$ long. Stipules linear-triangular, 10-17 $\times 0.8-1.2 \mathrm{~mm}$, persistent, margin subentire, apex acuminate. Leaves alternate to apically subopposite; petiole 3-40 $\times 2-7 \mathrm{~mm}$, blade flat, broadly ovate to ovate, $10.5-58 \times 9-45 \mathrm{~cm}, 1-1.3$ times longer than wide, base truncate, rounded or obtuse, peltate for 10-80 mm, peltate part flat, margin dentate, sometimes 2-lobed at widest part of blade, longest lobes to 50 $\mathrm{mm}$, upper surface pinkish red when young, dull green when old, basally with 0-4 extrafloral adaxial nectaries, $1.2-4.5 \times 0.7-2 \mathrm{~mm}$, marginal nectaries $0-9$ per side, 2-6(-18) mm from margin, 0.7-1 × 0.5-1 mm, lower surface brownish green; venation palmate, veins 7-11 per side, mostly ending at the margin. Inflorescences terminal, unisexual or bisexual, usually unbranched, axes greenish tawny, basally $2-5 \mathrm{~mm}$ thick; bracts $5-20 \times$ c. $1 \mathrm{~mm}$, bracteoles linear triangular $2.7-4.3 \times 0.4-0.6 \mathrm{~mm}$, persistent, margin subentire. Staminate inflorescences to $65 \mathrm{~cm}$ long, side branches to $30 \mathrm{~cm}$ long, with 2 or 3 flowers per node, nodes per branch to 130 . Pistillate inflorescences to 55 $\mathrm{cm}$ long, occasionally with side branches, to $10 \mathrm{~cm}$ long, nodes to 80 . Flowers lacking petals. Staminate flowers 6-9 mm diam.; pedicel 3-5.5 mm long; sepals 4 or 5, 3-5 × 1.3-3 mm, pale light cream to tan cream; stamens 60-85, pale light green to yellow, filaments $1-4 \mathrm{~mm}$ long, anthers $0.3-0.4 \times 0.2-0.3 \mathrm{~mm}$, pale light yellow; pistillode absent (stamens absent from middle of flower, centre sometimes with reduced wartlike appendices). Pistillate flowers 4-6 mm diam.; pedicel 1-4.5 mm long; calyx (3or) 4- or 5- (or 6-)lobed, connate on the base, 2.5-5 mm long, lobes 2-3 × 1.5-2.5 mm; ovary 3(-5)-locular, $2.5-3.5 \times 2.2-3 \mathrm{~mm}$, lobes with dense spines, not individually visible; style to $1.5 \mathrm{~mm}$ long; stigmas 2-6 mm long, yellow; staminodes sometimes present, also persistent in fruits. Fruits capsular, 10-21 $\times 14-20 \mathrm{~mm}$, with strong smell, yellow with reddish tinge, spines numerous, straight, thin, to $7 \mathrm{~mm}$ long, spines forming a continuous layer, rubbing off when touched; column 7-9 $\times 1-1.5 \mathrm{~mm}$. Seeds ellipsoid, 4.8-5.5 ×3-4.5 × 2-4 mm, dry, surface smooth, black; hilum c. $1 \times$ c. 1.3 $\mathrm{mm}$.

Distribution. From India (West Bengal) to southern China, continental Southeast Asia, Peninsular Malaysia, Singapore, Sumatra and Java.

Ecology. In Singapore it has been found in disturbed areas, evergreen forest and freshwater swamp forest. Across its range, it thrives mainly in regions with strong dry season which explains why it is scarce in Singapore and raises questions as to whether it is native or not. 


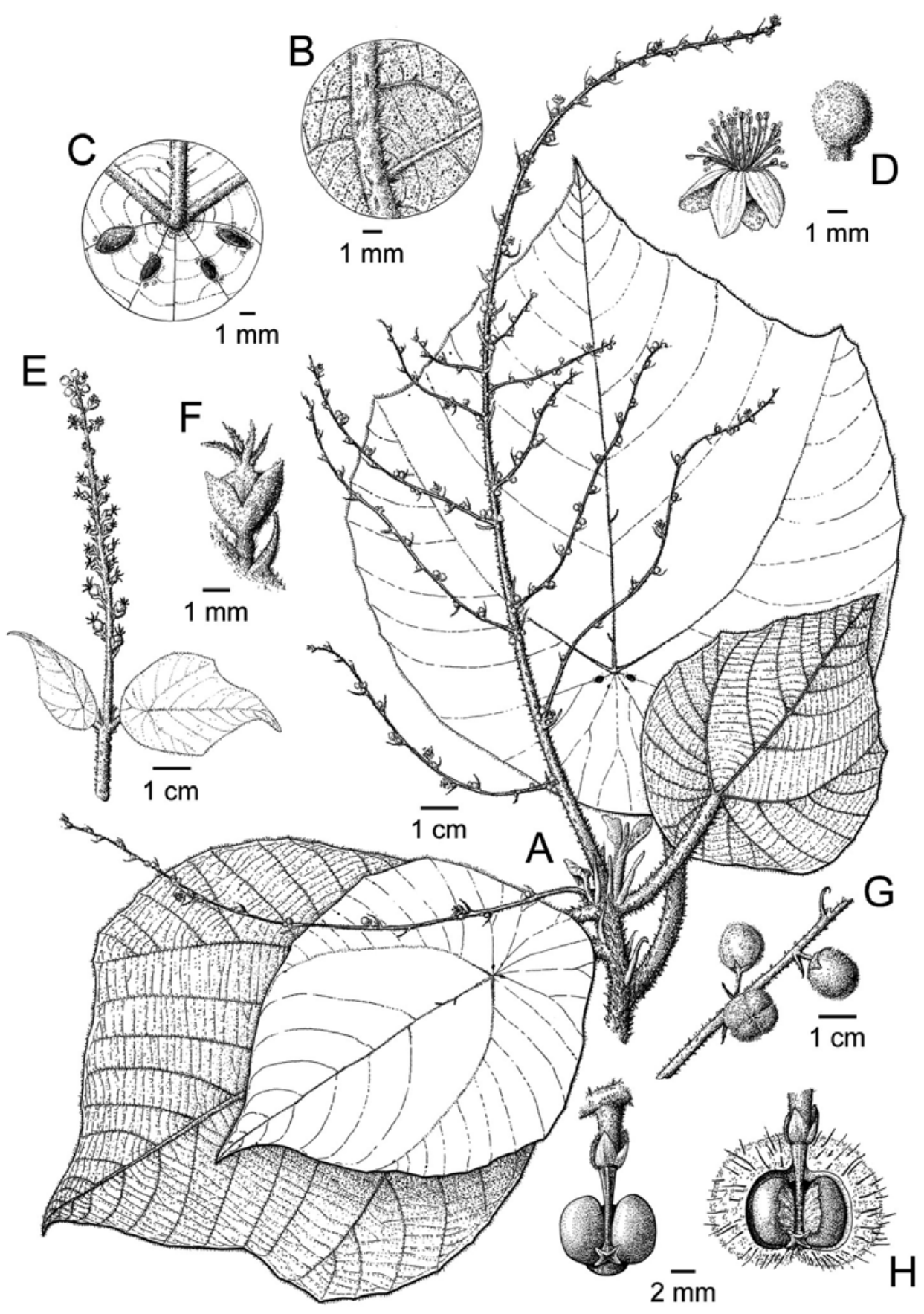

Fig. 4. Mallotus barbatus Müll.Arg. A. Habit with staminate inflorescence. B. Detail of leaf lower surface with glandular hairs. C. Base of leaf upper surface with extrafloral nectaries. D. Staminate flower and bud. E. Pistillate inflorescence. F. Pistillate flower. G. Immature fruits; $\mathbf{H}$. Dehisced fruit showing seeds and column. A \& D from Garrett 760; B, C, G \& H from Geesink et al. 5653; E \&F from Put 1618; all L. Drawn by Joanna Porck. 
Provisional IUCN conservation assessment. Globally Least Concern (LC) as it is a more or less weedy species frequently found in secondary forest. It is not assessed for Singapore as it is uncertain if it is native.

Specimens examined. SINGAPORE: Bukit Timah: Oct 1992, Metcalfe D129 (SINU); Kent Ridge Park: 19 Jun 2003, Wong \& Yeo s.n. (SINU); Nee Soon, 20 Sep 2010, Ang s.n. (SINU); [Boon Lay]: Tandjong Kling, 22 Jun 1961, Chin s.n. (SINU); Unlocalised: 1902, Lobb 297 (SING [SING0033692]).

Notes. Although herbarium specimens of this species had been correctly identified for some time, it had been overlooked in the Singapore literature. The earliest but undated specimen is from Lobb who collected in Singapore in the mid-nineteenth century. It is, however, known that there are problems with ensuring the correct locality data on Lobb specimens (Middleton \& Turner, 2019) so the earliest verified collections are only from 1961. As this species is weedy and easily observed and collected, this may suggest that the species is not actually native in Singapore. Given its scarcity in Singapore and the fact that it is native and widespread in the region, it is perhaps best to recognise it as a cryptogenic species rather than definitely native or definitely introduced.

6. Ptychopyxis bacciformis Croizat, J. Arnold Arbor. 23: 49 (1942). - TYPE: [Malaysia], British North Borneo [Sabah], Elphinstone Prov., Tawao, October 1922-March 1923, Elmer 21524 (lectotype A [A00048707], indirectly designated by Stoops \& van Welzen, Nordic J. Bot. 31: 97 (2013); isolectotypes HBG [HBG515863], K [K001079447, K001079448], L [L.2253131]).

Tree, dioecious, to $38 \mathrm{~m}$ high, dbh to $40 \mathrm{~cm}$; nodes not thickened; flowering branches $0.8-2.5 \mathrm{~mm}$ thick; axillary buds 1 or 2 to several, parallel to bundled, apex acute. Outer bark greyish to brownish, smooth (to superficially fissured), c. $0.5 \mathrm{~mm}$ thick; inner bark reddish to brown or pale yellowish outwards to pink-yellowish inward, granular, 3-6 mm thick; sapwood white to light brown, soft. Indumentum golden to brown, hairs simple. Stipules absent, but bud scales may appear as stipules. Leaves scattered to clustered at apex; petiole $0.7-3.1 \mathrm{~cm}$ long, 0.6-2 mm diam., transversely grooved, densely hairy, upper pulvinus $1.5-2.6 \mathrm{~mm}$ diam.; blade elliptic to obovate, 5.9-17.6 $\times$ 1.4-7.4 cm, 2.4-4.2 times longer than wide, base obtuse to acute, margin entire, apex emarginate to cuspidate, upper and lower surface green, also when dry, lower surface slightly lighter, glabrous to sparsely hairy on venation, midrib more densely hairy, extrafloral nectaries $0-2$ positioned abaxially at base, also absent or present along midrib and between veins, occasionally frequent here, apically absent, veins pinnate, 7-15 per side. Inflorescences panicles with short side-branches, per axil single to a few, then always staminate, to $16 \mathrm{~cm}$ long when staminate, to $10.5 \mathrm{~cm}$ long when pistillate and in fruit; staminate bracts $1.2-2.7 \times 0.4-0.7 \mathrm{~mm}$, pistillate bracts $2.3-5 \times$ 0.7-1 mm. Flowers: only staminate flowers known, green to yellow, 4-4.5 × 2.5-5.6 
$\mathrm{mm}$; pedicel short; calyx 3-lobed, green, lobes basally fused, triangular to ovate to elliptic, $1.9-3.1 \times 1.4-2.9 \mathrm{~mm}$, recurved, outside densely hairy, inside (occasionally) hairy; filaments $1-2 \times 0.1-0.2 \mathrm{~mm}$, white; anthers $0.5-0.9 \times 0.2-0.6 \mathrm{~mm}$, connective triangular to rectangular, with an apical appendage; disc glands small, round to straplike. Fruits capsular, ovoid, with 1-4 shallow lobes, 9.5-20.5 mm diam., olive to bright yellow to orange, without appendages, generally 2 or more locules developed; wall $0.2-1.1 \mathrm{~mm}$ thick, outside wrinkled; columella present; locules 3 or 4 ; stigmas 3 or 4, persistent. Seeds ovoid, often with ridge on top, $8.5-12.1 \mathrm{~mm}$ diam., dry; sarcotesta white, sweet.

Distribution. Vietnam, Peninsular Malaysia, Singapore, Sumatra, Borneo and the Philippines.

Ecology. In Singapore it has only ever been collected from evergreen forest on Bukit Timah.

Provisional IUCN conservation assessment. Globally Least Concern (LC). Presumed nationally extinct in Singapore as it has not been collected or observed since 1969.

Specimen examined. SINGAPORE: Bukit Timah: 14 Oct 1969, Mhd Noor MN 674 (SING [SING0036103]).

Notes. Even though the single collection known from Singapore was collected some time ago, it had previously only been identified to genus.

\section{New record of naturalised species}

1. Acalypha arvensis Poepp., Nov. Gen. Sp. Pl. 3(3-4): 21 (1841). - Ricinocarpus arvensis (Poepp.) Kuntze, Revis. Gen. Pl. 2: 617 (1891). - TYPE: Peru, Maynas Prov., Yurimaguas, January 1831, Poeppig 2215 ('2115') (lectotype W [W0074853, W0074854; single specimen on 2 sheets], designated by Cardiel \& Muñoz, PhytoKeys 17: 8 (2012); isolectotypes F [F0042433F, F0042434F], G [G00383645], G-DC [G00324857], P [P04839414], W [W0021410, W1889-0105800]). See notes.

Description after Levin (2016: 167). Herbaceous annual, 20-80 cm tall, monoecious; branches erect to often ascending; flowering branches to $50 \mathrm{~cm}$ long, c. $2 \mathrm{~mm}$ diam. Indumentum of simple, erect hairs, these a mixture of short-pubescent and densely, rarely sparsely, hirsute, sometimes hispid, hairs, no glandular hairs. Stipules early caducous, triangular, c. $2.5 \times 2 \mathrm{~mm}$, aristate, sparsely hairy with hispid hairs. Leaves: petiole 5-40 mm long, hairy; blade rhombic-ovate to rhombic-elliptic, $2-12 \times 1.2-6.5$ $\mathrm{cm}, 1.6-2$ times as long as wide, chartaceous, base cuneate to rounded, margin serrate, teeth $0.5-1.5 \times 2-3.5 \mathrm{~mm}$, without a gland on tooth tip; apex obtuse to acute; sparsely hairy on both sides with hispid hairs; veins basally triplinerved, and 3-5 pairs along 
midrib. Inflorescences unisexual or bisexual, axillary; staminate peduncle 0.3-2.5 $\mathrm{cm}$ long, not stipitate-glandular, fertile portion 1.5-3(-6) $\mathrm{cm}$ long; pistillate peduncle 0.4-3 cm long, not stipitate-glandular, fertile portion $2.5-4(-8) \times 1-2 \mathrm{~cm}$; bisexual similar to pistillate, with staminate portion 4-7 mm long; allomorphic pistillate flowers common, terminal on pistillate and bisexual inflorescences. Bracts of normal pistillate flowers very densely crowded (inflorescence axis not visible between bracts), 6-12 $\times$ 4-6 mm, abaxial surface long-hirsute (hairs to $2 \mathrm{~mm}$ long) and stipitate-glandular; lobes 3-7, proximally deltate with linear tips of $1 / 2-2 / 3$ bract length, smooth; pistillate bracts of allomorphic flowers absent. Flowers lacking petals and disc. Staminate flowers very small, pedicel short; calyx 4-lobed; stamens 8, thecae 2, pendulous and vermiform. Allomorphic flowers with rudimentary pedicels if borne above staminate flowers or 10-18 mm if borne above normal pistillate flowers. Pistillate flowers: pistil 3-locular in normal flowers, (1- or) 2-locular in allomorphic flowers; styles multifid or laciniate. Fruits capsular, smooth, hispidulous; allomorphic fruits ovoid, 1.5-1.6 $\times$ 1.2-1.3 mm, muricate, sparsely to densely puberulent. Seeds 1.1-1.5 mm diam., dry, minutely pitted.

Distribution. Native to Mexico and tropical South America, but widely naturalising elsewhere.

Ecology. Naturalising in disturbed areas.

Specimens examined. SINGAPORE: Dairy Farm Road: 14 Apr 2009, Tan \& Ang s.n. (SINU); Singapore Botanic Gardens: nursery, 10 Feb 1955, Purseglove 4056 (L [L.2174659], SING [SING0282153]); Ridley Hall, 17 Jan 1995, Nura Abdul Karim NK 193 (SING [SING0035230]); Cluny Road, 1 Apr 1997, Lai 233 (SING [SING0008026]); Choa Chu Kang: 11 Dec 2005, Lee \& Leong SING2006-105 (SING [SING0090275]); Serangoon: Sungei Serangoon, 23 Dec 2003, Tan 1113 (SINU).

Notes. Cardiel \& Muñoz (2012) designated Poeppig 2215 (W) as the lectotype but considered Poeppig 2115 to be the same collection. Accordingly, one of the isolectotypes at $\mathrm{W}$ is numbered 2215 while the other is numbered 2115 . The two isolectotypes at $\mathrm{F}$ and the one at P are numbered 2215 but the one at G-DC is numbered 2115 and the one at $\mathrm{G}$ carries both numbers. The lectotype was divided and mounted on two sheets after being designated.

Acalypha arvensis is often considered to be a synonym of $A$. aristata Kunth, but that name is a synonym of Acalypha alopecuroidea Jacq. (Levin, 2016).

ACKNOWLEDGEMENTS. Geoff Levin is thanked for his help with Acalypha. Especially during this period of the Covid-19 pandemic, online resources, such as BHL, Global Plants and IPNI, have been irreplaceable. The first author thanks the Treub-Maatschappij for supporting the Ornstein chair in Tropical Plant Biogeography. 


\section{References}

Arias Guerrero, S. \& van Welzen, P.C. (2011). Revision of Malesian Endospermum (Euphorbiaceae) with notes on phylogeny and historical biogeography. Edinburgh $J$. Bot. 68: 443-482.

Cardiel, J.M. \& Muñoz, P. (2012). Synopsis of Acalypha (Euphorbiaceae) of continental Ecuador. PhytoKeys 17: 1-17.

Chong, K.Y., Tan, H.T.W. \& Corlett, R.T. (2009). A Checklist of the Total Vascular Plant Flora of Singapore: Native, naturalised and cultivated species. Singapore: Raffles Museum of Biodiversity Research, National University of Singapore.

Davison, G.W.H., Ng, P.K.L. \& Ho, H.C. (eds) (2008). The Singapore Red Data Book: Threatened Plants and Animals of Singapore, 2nd edition. Singapore: Nature Society (Singapore).

IUCN Standards and Petitions Subcommittee (2017). Guidelines for Using the IUCN Red List Categories and Criteria. Version 13. Prepared by the Standards and Petitions Subcommittee.

Keng, H. (1990). The Concise Flora of Singapore: Gymnosperms and Dicotyledons. Singapore: Singapore University Press.

Levin, G.A. (2016). Acalypha Linnaeus. In: Flora of North America Editorial Committee (eds) Flora of North America, vol. 12, p. 167. New York, Oxford: Oxford University Press

Middleton, D.J. \& Turner, I.M. (2019). History of taxonomic research in Singapore. In: Middleton, D.J., Leong-Škorničková, J. \& Lindsay, S. (eds) Flora of Singapore, vol. 1, pp. 15-36. Singapore: National Parks Board.

Ottens-Treurniet, M.A.D. \& van Welzen, P.C. (2016). A revision of the Malesian genus Blumeodendron (Euphorbiaceae). Blumea 61: 64-82.

Schaeffer, J. (1971). Revision of the genus Endospermum Bth. (Euphorbiaceae). Blumea 19: 171-192.

Sierra, S.E.C. \& van Welzen, P.C. (2005). A taxonomic revision of Mallotus section Mallotus (Euphorbiaceae) in Malesia. Blumea 50: 249-274.

Stoops, E. \& van Welzen, P.C. (2013). A revision of Ptychopyxis (Euphorbiaceae) in southeast Asia. Nordic J. Bot. 31: 94-112.

Thiers, B. (continuously updated). Index Herbariorum: A global directory of public herbaria and associated staff. New York Botanical Garden's Virtual Herbarium. http://sweetgum. nybg.org/ih/. Accessed 22 Jul. 2020.

Turner, I.M. (1993). The names used for Singapore plants since 1900. Gard. Bull. Singapore 45: 1-287. 